\title{
The school coexistence program as a strategy to develop harmonious relationships in schools
}

\section{El programa de convivencia escolar como estrategia para desarrollar relaciones armónicas en los centros escolares}

\author{
GARZA-ROSALES, Gerardo de Jesús†*, ELIZARRARÁS-RAMÍREZ, Élida, GARCÍA-MÁRQUEZ,
} Luz María and ACOSTA-SALUDADO, Rosa Margarita

Centro de Investigación e Innovación para el Desarrollo Educativo.

ID $1^{\text {st }}$ Author: Gerardo de Jesús, Garza-Rosales / ORC ID: 0000-0003-2641-6402, CVU CONACYT ID: 640612

ID $1^{\text {st }}$ Coauthor: Élida, Elizarrarás-Ramírez / ORC ID: 0000-0003-3792-8147, Researcher Publons ID: 3127065, CVU CONACYT ID: 846691

ID $2^{\text {nd }}$ Coauthor: Luz María, García-Márquez / ORC ID: 0000-0002-6449-464X, Researcher Publons ID: Luz María García Márquez, arXiv ID Author: Luzmariagarciamarque, CVU CONACYT ID: 811472

ID $3^{\text {rd }}$ Coauthor: Rosa Margarita, Acosta-Saludado

\begin{abstract}
According to the OCDE (2012) Mexico is the country with the mayor index of school violence throughout Latin America, because of this, the Government through the Ministry of Public Education, has undertaken actions inclined to identify and eradicate these practices in the classrooms of the country, educational programs that regulate this condition have been established. The objective of this research is to analyze the influence of the knowledge of these programs in the educational practice of the teacher in situations of bullying in basic education. The program that was used was Statistics with the matrix correlation statistic; It was applied to a population of 135 teachers in the metropolitan area of the lagoon (ZML) with a representative sample of 100 teachers from a primary school school zone, Gómez Palacio Durango, the sample selected for the research work is probabilistic, and Simple random sampling was analyzed. The analysis of the data produced by the research shows that there is insufficient knowledge of the programs that contribute to the problems that affect school life within the institutions of primary education.
\end{abstract}

\begin{abstract}
Resumen
Según la OCDE (2012) México es el país con mayor índice de violencia escolar en toda América Latina, porque esto, el Gobierno a través del Ministerio de Educación Pública, ha emprendido acciones inclinadas a identificar y erradicar estas prácticas en las aulas del país, se han establecido programas educativos que regulan esta condición. El objetivo de esta investigación es analizar la influencia del conocimiento de estos programas en la práctica educativa del profesor en situaciones de acoso en la educación básica. El programa que se utilizó fue Estadísticas con la estadística de correlación de matriz; Se aplicó a una población de 135 profesores en el área metropolitana de la laguna (ZML) con una muestra representativa de 100 maestros de una zona de la escuela primaria, Gómez Palacio Durango, la muestra seleccionada para el trabajo de investigación es probabilística, y Simple se analizó el muestreo aleatorio. El análisis de los datos producidos por la investigación muestra que no hay suficiente conocimiento de los programas que contribuyen a los problemas que afectan la vida escolar dentro de las instituciones de educación primaria.
\end{abstract}

School harassment regulations, Healthy and peaceful coexistence, Basic education
Normatividad de acoso escolar, Convivencia sana y pacífica, Educación básica

Citation: GARZA-ROSALES, Gerardo de Jesús, ELIZARRARÁS-RAMÍREZ, Élida, GARCÍA-MÁRQUEZ, Luz María and ACOSTA-SALUDADO, Rosa Margarita. The school coexistence program as a strategy to develop harmonious relationships in schools. A superior experience. Journal-Economic History. 2019. 3-5: 14-20.

\footnotetext{
* Correspondence to Author (email: ciide08.educacion@ durango.gob.mx)

$\dagger$ Researcher contributing as first author
} 


\section{Introduction}

There is a general concern about the issue of school coexistence and the different problems in this regard, such as bullying, so alternatives have been implemented to prevent it, or where appropriate, reduce it, as well as various strategies to foster peaceful relationships within Basic education schools.

For education to reach the maximum achievement of these criteria, the Ministry of Public Education, through the Undersecretariat of Basic Education and within the framework of educational reform, promotes the Basic Improvement System, which includes the attention of four priorities: Normality Minimum of school operation, Ensure the bases for relevant and lasting learning, Stop and reverse school dropout and Healthy and peaceful coexistence (SEP, 2014).

The objective of this work is to analyze from the teacher's perspective the causes for which this phenomenon continues to occur, for this reason it will be developed under a phenomenological approach. It is intended with the analysis of the causes that cause bullying according to teachers, to establish relevant elements to avoid continuing to present this phenomenon in schools.

The value of this study lies in the search for those factors that hinder healthy and peaceful coexistence in schools, since with the detection of these it can be given a methodological utility, presenting applicable recommendations in schools so that they are free of violence.

\section{Justification}

There are many factors that have been changing the behavior of people within society in Mexico in recent years, for example the political situation with its reforms to the constitution, have caused the economic level of middle class families to fall significantly and lower-class families stay that way or worse living in some cases in precarious conditions, this situation forces parents to seek to increase their income to survive and this causes them to spend all day working both father and mother, and their children spend most of their time alone, and this generates family tension, arguments, poor tolerance and is reflected in the behavior of the students.
In 2012, based on the Reforms that were made to the Constitution of Mexico, it was determined that the Government formed the National Development Plan 2013-2018 where five national goals are specified: prosperous Mexico, Mexico with global responsibility, inclusive Mexico, Mexico in peace and Mexico with quality education (Official Journal of the Federation, 2013).

The national goal of Mexico with quality education is the responsibility of the Ministry of Public Education, to achieve it the Sectorial Education Program (PSE) was designed with the purpose of raising the quality of education with equity (Official Journal of the Federation, 2013).

During this process, some articles had to be modified to obtain this goal, as in the third article that talks about the education of our country where four criteria of how education should be in our country are described: Democratic, National, Contribute to an improvement of the human coexistence and of Quality (Official newspaper of the federation, 2017).

For education to reach the maximum achievement of these criteria, the Ministry of Public Education, through the Undersecretariat of Basic Education and within the framework of the Educational Reform, promotes the Basic Improvement System, which includes the attention of four priorities: Normality Minimum of school operation, Ensure the bases for relevant and lasting learning, Stop and reverse school dropout and Healthy and peaceful coexistence (SEP, 2014).

Based on the search for quality in education, an aspect that has not improved in years is observed, according to the OECD (2012) Mexico occupies the first place in school violence, thanks to the reforms in the articles in recent years have Implemented national and state regulations to regulate this condition in schools, programs have also been designed to prevent bullying, but there is no significant progress on this issue. This research is carried out with the objective of finding in the application of the current state bullying rules of Coahuila and Durango and the national program for school coexistence, the characteristics that influence the development of the Healthy and Peaceful Coexistence of students in the primary. 
The educational practice for this research is carried out in the Lagunera Region, which is why the geographical and population conditions that allowed obtaining a reliable sample in the state of Coahuila and Durango to which the Laguna Region belongs belong.

\section{Problem}

In the 1970s, Olweus was the first to use the term "bullying" with the bullying approach in his research; He began the first investigation in the world with systematic intimidation where his results were published in Sweden in 1973 and in the USA in the year 1978 in the book entitled Aggression in schools: Bullyies and aggressive children. In 1981 he proposed the publication of a law against bullying so that students could avoid verbal and physical aggressions, humiliations repeatedly, but it was until 1990 that legislation against bullying was established by the parliamentary groups of Sweden and Norway (Castillo, 2011).

There are statistical data about the time in which this situation of bullying began to be observed in the schools of Mexico, in 2008, the National Institute of Pediatrics said that bullying between students in schools is constantly increasing, the silence of Students who are victims and students who are witnesses, has been causing that there is no real data on the number of students victims of harassment and therefore there is misinformation about the magnitude of this problematic situation (SEP, 2013).

According to the Organization for Economic Cooperation and Development in the TALIS report (OECD, 2009) in which the teaching-learning circumstances of 23 countries including Mexico are studied, a statement is made of one of the greatest requests of teachers, have more and better training and education for their professional development and for the management of the behavior of students in class.

\section{Objectives}

General objective.

Determine the influence of the application of the National School Coexistence Program as a strategy to develop harmonious relationships in the primary schools of Gómez Palacio Durango.

\section{Theoretical framework}

\section{School Coexistence}

For Ianni (1998), school coexistence is one of the most important issues in education, he considers that learning is "the process by which a subject acquires or develops a new consciousness and knowledge, which provide new meanings" and coexistence It enriches this process.

According to Gomes Da Costa (2005), in his pedagogy of presence, he considers it important to rescue the positive behavior of students in difficulties that they may present, avoiding classifying them into categories based only on their deficiencies, that is, taking advantage of living spaces between students, parents and teachers so that they are a source of initiative, freedom and commitment to themselves.

The bullying that has recently occurred within the schools of Mexico, has caused the Mexican federal government to consider this situation as a public policy goal that must be addressed as a priority.

It is sought that from the educational institutions there is an alliance between supervisors, principals and teachers, with mothers, fathers, grandparents or guardians, to care for, protect and educate students of different educational levels who are the most important figures in education.

At this time, educational institutions are recognized as the space where organized, coordinated environments are managed, which are responsible for training students socially through healthy coexistence and prevention against violence. A society with a democratic, peaceful, respectful and inclusive school life is considered to provide learning opportunities for all students.

Coexistence must have the intention of forming in individuals the values, attitudes and skills that are required to integrate into a society such as: respectful, supportive and democratic treatment among its members. In order to develop an environment of healthy and peaceful coexistence in schools, it is necessary to capture the management, planning, coordination and evaluation of the actions in this area in an adequate and relevant way. 
Gagné (1970) considers that the interrelation between person and environment, generates in individuals changes of behavioral, behavioral and even disposition or attitude towards a part or all of reality; This is due to the maturing changes in the experience of experiences and their repetition.

On the other hand Levinas in his theory of the pedagogy of the other mentions that it is the responsibility towards the other that makes the humanity of the human being possible; what it is about is the other, his needs and his life, and by placing him in the first place we are obliged to respond ethically to him. (Mínguez et al., 2016). In recent years, the events related to the harassment that students in Mexico live in elementary schools have increased daily, thereby impacting school dynamics on the entire teaching-learning process, so it is important to recognize and analyze the causes and establish lines of action to overcome these difficulties.

As one of the main priorities of the government is to promote lines of action that help establish a social coexistence of respect and appreciation of plurality, through the Secretariat of Public Education, in the Undersecretariat of Basic Education, established as an action for intervention in the training and prevention field in schools, the National School Coexistence Program (SEP, 2014), with the intention of promoting a school environment and culture that facilitates the learning and development of all students in basic education, through establishment of respectful and collaborative interpersonal relationships, in response to the need for healthy coexistence in schools, as well as for the improvement of educational quality.

\section{National School Coexistence Program}

The National School Coexistence Program (2014) aims to provide financial support and educational materials to schools through the Local Educational Authorities (AEL). These materials propose a series of activities that address work issues based on strengthening of the values for the development of emotional and social skills of the students, they also favor the participation and support of the family and the community, in favor of living together.
Its purpose is to contribute to the strengthening of an inclusive, democratic and peaceful coexistence and of the rights and values of students, through dialogue and the search for agreements in order to maintain better relations of coexistence inside and outside the school.

For Jares (2004) there is a real need to learn to live in a respectful and supportive way among all people, this must be taught at home and reinforced at school.

\section{Importance of strengthening harmonic relationships in schools}

A task that belongs to all of us is to build a respectful and peaceful society, in which coexistence prevails between the different people and groups that compose it. All agents involved in education, we are directly or indirectly responsible for the transformation of school climates, because coexistence and peaceful environments are built and, therefore, we all have an essential role in these actions.

This task involves a slow process and a change of individual and collective mentality, and, in this change, education acquires absolute relevance in the development of values, attitudes and skills that sustain peaceful coexistence models (Geuz, s.d.).

The national education system and the different state educational structures, are working on the design and implementation of plans, projects and programs aimed at developing harmonic environments, they establish different strategies that must be implemented within schools and classrooms in Basic and compulsory education. All with the firm idea of preventing violence and promoting conflict resolution by peaceful means; However, the task has not been simple, it implies coresponsibility. Ortega in 1997, (as cited in Geuz, $\mathrm{sd})$, "... in the educational center, coexistence is understood as the framework of interpersonal relationships that occur between all members of the educational community, and in which processes are configured of communication, feelings, values, attitudes, roles, status and power ". This network of relationships is affected by different problems or conflicts: indiscipline, interpersonal conflicts, abuse between classmates, disruption in the classroom, absenteeism, vandalism, etc. 
All this depends on various factors that affect the quality of living in each school. Among others, the main ones are: interpersonal relationships, conflict resolution, regulations or the system of order and discipline, the participation of different sectors of the educational community, the teaching-learning methodology and the classroom management.

The response of schools to problematic situations and their transformative role must be based on a global model of school life. This implies, in the first place, the direct involvement of all and all: teachers, management teams, students, families, non-teaching staff and other environmental agents; secondly, a global model involves selecting and implementing a series of programs or strategies that address at least the acquisition or development of skills and competencies at the classroom level, the collaborative resolution of conflicts, regulations and channels of participation in the center.

\section{Research methodology}

We considered 100 primary school teachers belonging to a school zone of Gómez Palacio Durango, corresponding to the metropolitan area of the lagoon (ZML) that teach grades 1 through 6; 100 teachers The sample selected for the research work is probabilistic, and simple random sampling was used.

According to the population sample, the level of studies of the teachers subject to research is varied where it is observed that there are studies of Basic Normal, Bachelor and Master; They also have different years of service, from new incomes that have not yet reached the year, to teachers with more than 30 years, that is, they are young adults and middle adults (Papalia, 1992). Regarding human resources, the authorization of the supervisor and executives of the educational zone was provided to carry out the investigation.

In the present investigation the Statistica statistician was used, in which a correlational link was made, since it was necessary to know the influence between the application of the programs for school coexistence, for their attention in the school centers. This research corresponds to the field of non-experimental, and can be classified as descriptive transectional.
The instrument is divided into five nominal variables (Hernández et al; 2008), the first indicates the gender of the interviewee, the second indicates the level of study considering Basic Normal, Bachelor, Master's or Doctorate, the third indicates the years of service of the teacher from new entry to 31 onwards, the fourth variable on the degree it imparts and finally the context in which the primary is whether urban, urban marginal or rural.

\section{Results}

With the information obtained, an analysis of the research phenomenon is shown, about the influence of the school coexistence program on the development of healthy and peaceful coexistence in students of basic education. According to descriptive statistics, the first task is to describe the data, values or scores obtained for each variable; Matrix correlations were used to compare significant variables with all others.

When measuring the degree of covariation between different linearly related variables, it indicates whether one variable is directly or indirectly proportional to another; thus, it gives us a reference of which variables show greater relation and which are very dispersed (weak variables with little relation). The Statistica program was used with a significance level of 0.00000000001 . The statistician was used considering the main variables of each category, where the following correlations were found:

\begin{tabular}{|l|c|}
\hline \multicolumn{1}{|c|}{ Variable } & $\begin{array}{c}\text { I identify the } \\
\text { national school } \\
\text { coexistence } \\
\text { program (nscp) }\end{array}$ \\
\hline $\begin{array}{l}\text { I identify the educational priority } \\
\text { healthy and peaceful coexistence }\end{array}$ & 0.630301 \\
\hline $\begin{array}{l}\text { I analyze the elements of healthy and } \\
\text { peaceful coexistence }\end{array}$ & 0.670470 \\
\hline $\begin{array}{l}\text { I identify the actors healthy and } \\
\text { peaceful coexistence }\end{array}$ & 0.637072 \\
\hline $\begin{array}{l}\text { I identify dimensions of healthy and } \\
\text { peaceful coexistence }\end{array}$ & 0.623604 \\
\hline I am clear about PNCE & 0.910971 \\
\hline It is understood where PNCE emerged & 0.713969 \\
\hline PNCE objective is understood & 0.845357 \\
\hline I identify PNCE features & 0.837007 \\
\hline I identify where PNCE is applied & 0.789544 \\
\hline I have clear PNCE guidelines & 0.702585 \\
\hline $\begin{array}{l}\text { I identify characteristics of a favorable } \\
\text { teaching-learning environment }\end{array}$ & 0.730482 \\
\hline
\end{tabular}

Table 1 General knowledge of the PNCE Source: self made 
Table 1 General knowledge of the PNCE shows that teachers regarding the general knowledge of the National School Coexistence Program, it is clear that there is a program focused on improving relations in the educational field, but they largely ignore the basic information of the program, such as where and why it arises, where it is applied and what the monitoring is. Teachers identify what are the aspects, elements to develop a healthy and peaceful coexistence within the school, they know that it is the commitment of all educational actors.

\begin{tabular}{|l|c|}
\hline \multicolumn{1}{|c}{ Variable } & $\begin{array}{c}\text { It is understood } \\
\text { where the } \\
\text { national school } \\
\text { coexistence } \\
\text { program (pnce) } \\
\text { came from }\end{array}$ \\
\hline I identify the dimensions of school life & 0.648013 \\
\hline $\begin{array}{l}\text { I identify the processes involved in a } \\
\text { peaceful dimension }\end{array}$ & 0.635708 \\
\hline I identify PNCE & 0.713969 \\
\hline I have clear PNCE guidelines & 0.768482 \\
\hline It includes objectives of the PNCE & 0.845880 \\
\hline I identify PNCE characteristics & 0.814544 \\
\hline I identify where PNCE is applied & 0.735558 \\
\hline I have clear PNCE guidelines & 0.868315 \\
\hline $\begin{array}{l}\text { I identify characteristics of a favorable } \\
\text { teaching-learning environment }\end{array}$ & 0.615336 \\
\hline
\end{tabular}

Table 2 PNCE Origin

Source: self made

In Table 2 Origin of the PNCE, it is observed that teachers consider that the PNCE arises from the need to establish a peaceful and cordial environment among educational actors, they mention that it is important to know more about the PNCE, since it is necessary to establish a favorable teaching-learning environment with the participation of teachers, students and parents.

\begin{tabular}{|c|c|}
\hline Variable & $\begin{array}{l}\text { I am clear about the } \\
\text { national school } \\
\text { coexistence program } \\
\text { (pnce) }\end{array}$ \\
\hline $\begin{array}{l}\text { I identify the educational } \\
\text { priority healthy and peaceful } \\
\text { coexistence }\end{array}$ & 0.674402 \\
\hline $\begin{array}{l}\text { I understand the purpose of } \\
\text { healthy and peaceful } \\
\text { coexistence }\end{array}$ & 0.661516 \\
\hline $\begin{array}{l}\text { I analyze the elements that } \\
\text { develop healthy and peaceful } \\
\text { coexistence }\end{array}$ & 0.710387 \\
\hline $\begin{array}{l}\text { I identify the actors that } \\
\text { participate in the priority of } \\
\text { healthy and peaceful } \\
\text { coexistence }\end{array}$ & 0.681271 \\
\hline $\begin{array}{l}\text { I understand the meaning of } \\
\text { school life }\end{array}$ & 0.616297 \\
\hline $\begin{array}{l}\text { I identify the dimensions of } \\
\text { school life }\end{array}$ & 0.689712 \\
\hline
\end{tabular}

\begin{tabular}{|l|c|}
\hline $\begin{array}{l}\text { I am clear about the inclusive } \\
\text { dimension of school life }\end{array}$ & 0.673669 \\
\hline $\begin{array}{l}\text { I identify the actors involved in } \\
\text { the inclusive dimension }\end{array}$ & 0.682666 \\
\hline $\begin{array}{l}\text { I am clear about the democratic } \\
\text { dimension of school life }\end{array}$ & 0.659077 \\
\hline $\begin{array}{l}\text { I am clear about the peaceful } \\
\text { dimension of school life }\end{array}$ & 0.628035 \\
\hline $\begin{array}{l}\text { I identify the processes involved } \\
\text { in the peaceful dimension }\end{array}$ & 0.626525 \\
\hline $\begin{array}{l}\text { I identify the national program } \\
\text { for school coexistence }\end{array}$ & 0.910971 \\
\hline $\begin{array}{l}\text { I understand where the PNCE } \\
\text { came from }\end{array}$ & 0.768482 \\
\hline $\begin{array}{l}\text { I understand the objective of the } \\
\text { PNCE }\end{array}$ & 0.926326 \\
\hline $\begin{array}{l}\text { I identify the characteristics of } \\
\text { the PNCE }\end{array}$ & 0.915200 \\
\hline $\begin{array}{l}\text { I identify to what degree the } \\
\text { PNCE is focused }\end{array}$ & 0.892806 \\
\hline $\begin{array}{l}\text { I am clear about the PNCE } \\
\text { guidelines }\end{array}$ & 0.66969698 \\
\hline $\begin{array}{l}\text { I identify the characteristics of a } \\
\text { favorable teaching-learning } \\
\text { environment }\end{array}$ & 0.761255 \\
\hline $\begin{array}{l}\text { I establish a favorable teaching- } \\
\text { learning environment in the } \\
\text { classroom }\end{array}$ & 0.637145 \\
\hline $\begin{array}{l}\text { I identify the characteristics to } \\
\text { develop the cognitive abilities of } \\
\text { the students }\end{array}$ & $\begin{array}{l}\text { I promote in students the } \\
\text { development of their cognitive } \\
\text { abilities }\end{array}$ \\
\hline $\begin{array}{l}\text { Propitious with students the } \\
\text { development of their socio- } \\
\text { emotional skills }\end{array}$ & 0.676630 \\
\hline
\end{tabular}

Table 3 PNCE as an Educational Program Source: self made

It is shown in the PNCE Table as an Educational Program that teachers know very little about this national proposal, for their part, to be able to develop activities where healthy and peaceful coexistence is promoted, pedagogical activities work in the group in a democratic way, for for example, regarding the decision-making of some activity and / or task, or in the establishment of lines of work; they favor the educational inclusion not only in the groups where the students are with some educational need, but it extends to all the groups, they seek to make a dynamic of collaborative work among the students.

\section{Conclusions}

Teachers know in a very general way the National School Coexistence Program, they know that it focuses on improving healthy and peaceful coexistence among their students, to develop a harmonious environment in schools, but they consider that it is not enough to improve relations interpersonal among all educational actors.

GARZA-ROSALES, Gerardo de Jesús, ELIZARRARÁS-RAMÍREZ, Élida, GARCÍA-MÁRQUEZ, Luz María and ACOSTA-SALUDADO, Rosa Margarita. The school coexistence program as a strategy to develop harmonious relationships in schools. A superior experience. Journal-Economic History. 2019 
They propose low scores in the peaceful dimension of the PNCE, which means that, in order to contribute to the issue of coexistence in institutions, there must be a transformation from the educational structure, assuming the need for teacher training in this regard, and implement actions in this regard.

For Gomes (2003), school coexistence can only be learned if lasting changes in behavior can be established, such as the application or establishment of a regulation that allows an active adaptation to the personal and social environment of each of them. Teachers comply only with the activities that are regulated or implemented in the School Continuous Improvement Program (PEMC), consider that the performance of their practice is adequate for the integral development of their students, this makes it very difficult for them to observe the reality they throw The results of the different academic and social, cultural, sports evaluations and consequently omit improvement processes.

Finally, it is recommended to include in the PEMC, various pedagogical strategies that promote healthy and peaceful coexistence, the elements that frame the National School Coexistence Program and measure progress on a regular basis on the application of the program.

\section{References}

Geuz (s.d.) Programas y estrategias parala convivencia escolar. Recuperado de: http://www.leioa.net/vive_doc/guia_convivenci a_cast.pdf

Gomes, C. A. (2005). La Pedagogía de la Presencia. Edit. Losada. Argentina

Hernández, R., Fernández, C. y Baptista, P. (2008). Metodología de la investigación. México: McGraw-Hill Interamericana.

Ianni, N., Pérez, E. (1998). La convivencia en la escuela: un hecho una construcción. Hacia una modalidad diferente en el campo de la prevención. Grupos e Instituciones. Ed. Paidós. Buenos Aires.

Jares, X. (2004), Educación y conflicto. Guía de educación para la convivencia, Madrid, Editorial Popular.
OCDE (2012) PISA Students well being country note México. Recuperado de https://www.oecd.org/pisa/PISA2015-StudentsWell-being-Country-note-Mexico.pdf

Papalia D. E. y Wendkos O.S. (1992). Desarrollo Humano México: Mc Graw Hill, $4^{\mathrm{a}}$ edición.

SEP (2014, agosto). Programa Nacional de Convivencia Escolar. Subsecretaría de Educación Básica Dirección General de Desarrollo de la Gestión Educativa. México DF 